\title{
The Role of Silicon (Si) in Increasing Plant Resistance against Insect Pests Review article
}

\author{
N. SAKR \\ Department of Agriculture, Atomic Energy Commission of Syria, Damascus, P.O. Box 6091, Syria
}

(Received: 26 January 2017; accepted: 6 March 2017)

\begin{abstract}
Silicon $(\mathrm{Si})$ is reported to improve plant resistance to a range of biotic and abiotic stresses, with consequent yield increases. Silicon plays an important role in providing defense for crops of great economic importance against insect pests attack. In this study, the interaction between plants treated with silicon and reduced insect damage was reviewed. The current review presents the agronomic importance of silicon in plants, the control of insect pests in different major crop plants by silicon treatment, the different mechanisms of silicon-enhanced resistance, and the absence of silicon effects on insect pests. By integrating the data presented in this paper, a good knowledge of the association between silicon treatment, increasing plant resistance, and decreasing insect pest damage could be attainted.
\end{abstract}

Keywords: insect pest-plant interactions, insect pest damage, silicon application.

One of the restricting factors of plant crops is susceptibility to insect pest infestation. Chemical control is widely used, but due to limitations, such as high cost of pesticides, insecticide persistence in food and/or environment, possibility of selection of insecticide-resistant populations to the products traditionally used and increased probability of harmfulness to non-target insects (Denholm and Rowland, 1992), new control alternatives should be sought.

Nutrition management with silicon $(\mathrm{Si})$ can improve plant resistance and protect against abiotic stresses and decreases the incidence of insects and diseases, with consequent yield and productivity increase (Ma, 2004; Reynolds et al., 2009, 2016; Liang et al., 2007, 2015a,b; Van Bockhaven et al., 2013; Sakr, 2016a,b). Therefore, the addition of silicon fertilizer is a potential strategy and alternative management method to chemical control of insect pest thought the reduction in insect performance and plant damage. Silicon enhances plant resistance to a wide range of insect pests including borers and sap-feeding insects (Reynolds et al., 2009, 2016; Liang et al., 2015a).

Applications of silicon treatments have many agricultural benefits including improved plant growth, photosynthetic capacity, tolerance to frost, plant architecture, tolerance to water stress, quality of raw materials and productivity, yield and positive interactions with applied N, P and K fertilizers (Jones and Handreck, 1967; Savant et al., 1997,

*E-mail: ascientific@aec.org.sy 
1999). The effects of silicon on the reduction in the incidence and severity of phytopathognic fungi, bacterial and viral pathogens, and insect pest attack have been widely reported in several crop plant species (Ma, 2004; Reynolds et al., 2009, 2016; Van Bockhaven et al., 2013; Liang et al., 2015a,b; Sakr, 2016a,b). Most importantly, silicon enhanced plant resistance against a multitude of stresses without the occurrence of resistance trade-offs and/or growth and yield penalties (Ma, 2004; Ma and Yamaji, 2006; Epstein, 2009; Van Bockhaven et al., 2013; Liang et al., 2015b).

Based on the literature, two major defense mechanisms due to silicon application against insect pest damage have been documented: physical defense and biochemical defense (Reynolds et al., 2009, 2016; Liang et al., 2015a). Physical defense is associated with an accumulation of absorbed silicon in the epidermal tissue as a mechanical barrier in leaf epidermis cells, increasing hardness that causes wear to insect mandibles and reducing digestibility. Biochemical defense is related to soluble silicon being involved in induced biochemical defense to insect pest attack through the enhanced production of defensive enzymes and phenolic compounds. Also, silicon can induce both types of defense mechanisms by causing decreased digestibility capacity, increased abrasiveness of plant tissues, and enhanced production and accumulation of chitinases, peroxidases, lignin and phenolics (Reynolds et al., 2009, 2016; Liang et al., 2015a).

To date, numerous studies have documented the ability of silicon application to improve resistance of plants to insect attack and reduce insect growth and reproduction in several plant crops (Table 1). Physical and/or biochemical protection systems due to silicon treatments against pest infestation have been shown for all insect feeding guilds: lepidopteran borers, phloem-feeding insects and xylem-feeding insects (Reynolds et al., 2009, 2016; Liang et al., 2015a). In order to understand the complex interaction between silicon applications and insect pest resistance in plants, this review aims to present the agricultural importance of silicon in plants, to underline the control of insect pests in different major crop plants by silicon treatment, to refer to different mechanisms of silicon-enhanced resistance, and to explain the presence of nil effects of silicon on insect pests.

\section{Silicon uptake and accumulation in plants in relation with plant resistance to insect pests}

Silicon is the second most abundant element in the earth's crust mass (27.70\%), and is considered as the most important secondary mineral in the formation of soils (Lowenstam, 1981). In soil solution, silicon occurs mainly as monosilicic acid $\left(\mathrm{H}_{4} \mathrm{SiO}_{4}\right)$ at concentrations ranging from 0.1 to $0.6 \mathrm{mM}$ and is taken up by plants in this form (Epstein, 1994; Savant et al., 1997; Ma and Takahashi, 2002). After its uptake, it is transported via xylem to all parts of the plant and deposited in the form of silica gel or biogenetic opal as immobile amorphous $\mathrm{SiO}_{2} \cdot \mathrm{nH}_{2} \mathrm{O}$ in cell walls, intercellular spaces of root and leaf cells as well as in bracts (Aston and Jones, 1976). The amorphous silica, deposited below the cuticle, forms a physical barrier called double-layer silicon-cuticle. It maintains the leaves erect, reduces the transpiration and digestibility, increases hardness and abrasiveness and protects the plants against insects and fungal attacks (Ma, 2004; Liang et al., 2015a). 


\section{Table 1}

Plant-insect associations on which the role of silicon in decreasing pest preference and growth rates has been observed

\begin{tabular}{|c|c|c|}
\hline Host plant & Insect pest & Reference \\
\hline \multirow[t]{4}{*}{ Wheat } & $\begin{array}{l}\text { Hessian fly Phytophaga destructor Say (Diptera: } \\
\text { Aphelinidae) }\end{array}$ & $\begin{array}{l}\text { McColloch and Salmon (1923); } \\
\text { Miller et al. (1960) }\end{array}$ \\
\hline & $\begin{array}{l}\text { Rose-grain aphid Metopolophium dirhodum Walker } \\
\text { (Hemiptera: Aphididae) }\end{array}$ & Hanisch (1981) \\
\hline & $\begin{array}{l}\text { English grain aphid Sitobion avenae Fabricius } \\
\text { (Hemiptera: Aphididae) }\end{array}$ & $\begin{array}{l}\text { Hanisch (1981); Dias et al. } \\
\text { (2014) }\end{array}$ \\
\hline & $\begin{array}{l}\text { Green bug Schizaphis graminum (Rondani) } \\
\text { (Hemiptera: Aphididae) }\end{array}$ & $\begin{array}{l}\text { Gomes et al. (2005); Goussain et } \\
\text { al. (2005); Costa et al. (2011) }\end{array}$ \\
\hline \multirow[t]{6}{*}{ Maize } & $\begin{array}{l}\text { Stalk-borer Chilo zonellus Swinhoe (Lepidoptera: } \\
\text { Pyralidae) }\end{array}$ & Sharma and Chatterji (1972) \\
\hline & $\begin{array}{l}\text { European corn borer Ostrinia nubilalis Hubner } \\
\text { (Lepidoptera: Pyralidae) }\end{array}$ & Rojanaridpiched et al. (1984) \\
\hline & $\begin{array}{l}\text { Stem borer Sesamia calamistis Hampson } \\
\text { (Lepidoptera: Noctuidae) }\end{array}$ & Setamou et al. (1993) \\
\hline & $\begin{array}{l}\text { Fall armyworm Spodoptera frugiperda Smith } \\
\text { (Lepidoptera: Noctuidae) }\end{array}$ & $\begin{array}{l}\text { Goussain et al. (2002); } \\
\text { Neri et al. (2005) }\end{array}$ \\
\hline & $\begin{array}{l}\text { Asian corn borer Ostrinia furnacalis Guenee } \\
\text { (Lepidoptera: Crambidae) }\end{array}$ & Horng and Chu (1990) \\
\hline & $\begin{array}{l}\text { Leaf corn aphid Rhopalosiphum maidis Fitch } \\
\text { (Hemiptera: Aphididae) }\end{array}$ & Almeida et al. (2015) \\
\hline \multirow[t]{11}{*}{ Rice } & $\begin{array}{l}\text { Asian rice stem borer Chillo suppressalis Walker } \\
\text { (Lepidoptera: Crambidae) }\end{array}$ & $\begin{array}{l}\text { Sasamoto (1961); Djamin and } \\
\text { Pathak (1967); Ma and Takahashi } \\
\text { (2002); Hou and Han (2010) }\end{array}$ \\
\hline & $\begin{array}{l}\text { Yellow stem borer Scirpophaga incertulas (Walker) } \\
\text { (Lepidoptera: Pyralidae) }\end{array}$ & $\begin{array}{l}\text { Panda et al. (1975); Rajamani et } \\
\text { al. (2013) }\end{array}$ \\
\hline & $\begin{array}{l}\text { Brown plant-hopper Nilaparvata lugens Stal } \\
\text { (Hemiptera: Delphacidae) }\end{array}$ & $\begin{array}{l}\text { Yoshihara and Sogawa (1979); } \\
\text { Rajamani et al. (2013); } \\
\text { He et al. (2015) }\end{array}$ \\
\hline & $\begin{array}{l}\text { White-backed plant-hopper Sogatella furcifera } \\
\text { Horvath (Hemiptera: Delphacidae) }\end{array}$ & $\begin{array}{l}\text { Kin and Heinrichs (1982); } \\
\text { Salim and Saxena (1992) }\end{array}$ \\
\hline & $\begin{array}{l}\text { African striped borer Chilo zacconius Bleszynski } \\
\text { (Lepidoptera: Pyralidae) }\end{array}$ & Ukwungwu (1990) \\
\hline & $\begin{array}{l}\text { Leaf rice roller Cnaphalocrocis medinalis (Guenee) } \\
\text { (Lepidoptera: Pyralidae Satyridae) }\end{array}$ & $\begin{array}{l}\text { Ramachandran and Khan (1991); } \\
\text { Nakata et al. (2008); } \\
\text { Ye et al. (2013); Han et al. (2015) }\end{array}$ \\
\hline & Stem-borer Chilo agamemnon Bleszynski & Soliman et al. (1997) \\
\hline & $\begin{array}{l}\text { Leaf miner Hydrellia prosternalis Deeming } \\
\text { (Diptera: Ephydridae) }\end{array}$ & Soliman et al. (1997) \\
\hline & $\begin{array}{l}\text { Green rice caterpillar Naranga aenescens Moore } \\
\text { (Lepidoptera: Noctuidae) }\end{array}$ & Nakata et al. (2008) \\
\hline & $\begin{array}{l}\text { Gall midge Orseolia oryzae Wood-Mason } \\
\text { (Diptera:Cecidomyiidae) }\end{array}$ & Rajamani et al. (2013) \\
\hline & $\begin{array}{l}\text { Green leaf hopper Nephotetticx virescens Distant } \\
\text { (Hemiptera: Cicadellidae) }\end{array}$ & Rajamani et al. (2013) \\
\hline
\end{tabular}




\section{Table 1 continued}

\begin{tabular}{|c|c|c|}
\hline Host plant & Insect pest & Reference \\
\hline & $\begin{array}{l}\text { Sugarcane stem borer Diatraea saccharalis } \\
\text { Fabricius (Lepidoptera: Crambidae) }\end{array}$ & Sidhu et al. (2013) \\
\hline \multirow[t]{6}{*}{ Sugarcane } & $\begin{array}{l}\text { Sugarcane shoot-borer Chilo infuscatelus Snell } \\
\text { (Lepidoptera: Crambidae) }\end{array}$ & Rao (1967) \\
\hline & $\begin{array}{l}\text { Sugarcane scale Melanaspis glomerata (Green) } \\
\text { (Homoptera: Coccidae) }\end{array}$ & Agarwal (1969) \\
\hline & $\begin{array}{l}\text { Sugarcane top borer Scirpophaga excerptalis } \\
\text { Walker (Lepidoptera: Crambidae) }\end{array}$ & Gupta et al. (1992) \\
\hline & $\begin{array}{l}\text { Sugarcane stem borer Diatraea saccharalis } \\
\text { Fabricius (Lepidoptera: Crambidae) }\end{array}$ & Anderson and Sosa (2001) \\
\hline & $\begin{array}{l}\text { African sugarcane borer Eldana saccharina Walker } \\
\text { (Lepidoptera: Pyralidae) }\end{array}$ & $\begin{array}{l}\text { Keeping and Meyer (2002); } \\
\text { Meyer and Keeping (2005); } \\
\text { Kvedaras et al. (2007a,b); } \\
\text { Kvedaras and Keeping (2007); } \\
\text { Keeping et al. (2014) }\end{array}$ \\
\hline & $\begin{array}{l}\text { Sugarcane spittlebug Mahanarva fimbriolata Stal } \\
\text { (Hemiptera: Cercopidae) }\end{array}$ & Korndorfer et al. (2011) \\
\hline Ryegrass & $\begin{array}{l}\text { Argentine stem weevil Listronotus bonariensis } \\
\text { Kuschel (Coleoptera: Curculionidae) }\end{array}$ & Barker (1989) \\
\hline \multirow[t]{3}{*}{ Sorghum } & $\begin{array}{l}\text { Central shoot fly Atherigona indica infuscata } \\
\text { Malloch (Diptera: Anthomyiidae) }\end{array}$ & Ponnaiya (1951) \\
\hline & $\begin{array}{l}\text { Green bug Schizaphis graminum (Rondani) } \\
\text { (Hemiptera: Aphididae) }\end{array}$ & Carvalho et al. (1999) \\
\hline & $\begin{array}{l}\text { Sweet potato weevil Cylas formicarius Fabricius } \\
\text { (Coleoptera: Curculionidae) }\end{array}$ & Singh et al. (1993) \\
\hline Cucumber & $\begin{array}{l}\text { Whitefly Bemisia tabaci Gennadius } \\
\text { (Hemiptera: Aleyrodidae) }\end{array}$ & Correa et al. (2005) \\
\hline $\begin{array}{l}\text { Agrostis capillaries, } \\
\text { Brachypodium } \\
\text { pinnatum, Festuca } \\
\text { ovina, Lolium } \\
\text { perenne, and Poa } \\
\text { annua grass plants }\end{array}$ & $\begin{array}{l}\text { African armyworm Spodoptera exempta Walker } \\
\text { (Lepidoptera: Noctuidae) } \\
\text { Desert locust Schistocerca gregaria Forskal } \\
\text { (Orthoptera: Acrididae) }\end{array}$ & Massey et al. (2006) \\
\hline Cotton & $\begin{array}{l}\text { Leaf-worm Alabama argillacea Hubner } \\
\text { (Lepidoptera: Noctuidae) }\end{array}$ & Tomquelski et al. (2007) \\
\hline \multirow[t]{4}{*}{ Potato } & $\begin{array}{l}\text { Green peach aphid Myzus persicae Sulzer } \\
\text { (Hemiptera: Aphididae) }\end{array}$ & Gomes et al. (2008) \\
\hline & $\begin{array}{l}\text { Cucurbit beetle Diabrotica speciosa Germar } \\
\text { (Coleoptera: Chrysomelidae) }\end{array}$ & $\begin{array}{l}\text { Gomes et al. (2009); } \\
\text { Assis et al. (2012) }\end{array}$ \\
\hline & $\begin{array}{l}\text { Leaf-beetle Diabrotica spp. (Coleoptera: } \\
\text { Chrysomelidae) }\end{array}$ & da Silva et al. (2010) \\
\hline & Leaf-miners Liriomyza spp. (Diptera: Agromyzidae) & da Silva et al. (2010) \\
\hline $\begin{array}{l}\text { Deschampsia } \\
\text { caespitosa, } \\
\text { Festuca ovina, and } \\
\text { Lolium perenne } \\
\text { grass plants }\end{array}$ & $\begin{array}{l}\text { African armyworm Spodoptera exempta Walker } \\
\text { (Lepidoptera: Noctuidae) }\end{array}$ & Massey and Hartley (2009) \\
\hline
\end{tabular}


Table 1 continued

\begin{tabular}{|c|c|c|}
\hline Host plant & Insect pest & Reference \\
\hline Soybean & Whitefly $B$. tabaci & Ferreira et al. (2011) \\
\hline Peanut & $\begin{array}{l}\text { Silvering thrips Enneothrips flavens Moulton } \\
\text { (Thysanoptera: Thripidae) }\end{array}$ & Dalastra et al. (2011) \\
\hline Sunflower & $\begin{array}{l}\text { Sunflower caterpillar Chlosyne lacinia saundersii } \\
\text { Doubleday and Hewitson (Lepidoptera: } \\
\text { Nymphalidae) }\end{array}$ & Assis et al. $(2013,2015)$ \\
\hline Lemon & $\begin{array}{l}\text { Mediterranean fruit fly Ceratitis capitata } \\
\text { Wiedemann (Diptera: Tephritidae) }\end{array}$ & Mditshwa et al. (2013) \\
\hline $\begin{array}{l}\text { Portulaca grandif- } \\
\text { lora plants }\end{array}$ & $\begin{array}{l}\text { Mealy-bug Phenacoccus solenopsis Tinsley } \\
\text { (Hemiptera: Pseudococcidae) }\end{array}$ & Huang et al. (2014) \\
\hline Tomato & $\begin{array}{l}\text { Tomato leaf-miner Tuta absoluta Meyrick } \\
\text { (Lepidoptera: Gelechiidae) }\end{array}$ & dos Santos et al. (2015) \\
\hline Mandarin orange & $\begin{array}{l}\text { Citrus black-fly Aleurocanthus woglumi Ashby } \\
\text { (Homoptera: Aleyrodidae) }\end{array}$ & Vieira et al. (2016) \\
\hline
\end{tabular}

Epstein (1994) reported that the absorption of silicon by plants from the soil at differing rates depend on genotype, its concentration in the soil and environmental conditions. In plant tissues, silicon content varies considerably with the species, ranging from 0.1 to $10 \%$ silicon on a dry weight basis (Ma and Takahashi, 2002). Generally, plants can be classified as silicon accumulators, silicon non-accumulators or silicon excluders (Ma and Yamaji, 2006). Plants require large quantity of silicon (concentrations greater than $1 \%$ of dry weight) are considered accumulators (Epstein, 1999). In this category belong plants in Poaceae family, such as corn, oats, rye, wheat, and rice which accumulates silicon at rates up to $10 \%$ of dry weight (Takahashi et al., 1990). Plants are considered neutral of silicon at concentrations less than $0.1 \%$ of dry weight (Epstein, 1999). Most dicotyledons are unable to accumulate high levels of silicon in their shoots, such as tomatoes, soybeans and cucumber.

Plant resistance in restricting pest feeding may not be simply related to the total quantity of silicon per se, but due to the site, arrangement and organization of silicon in the plant. Sorghum resistance to central shoot fly Atherigona indica infuscata Malloch (Diptera: Anthomyiidae) did depend upon the early formation of irregularly shaped silica deposits in the epidermis of the leaf sheath (Ponnaiya, 1951). Miller et al. (1960) found that the level of resistance to the Hessian fly Phytophaga destructor Say (Diptera: Aphelinidae) depends mainly on the distribution of silica bodies in leaf sheaths of wheat and oat cultivars. In susceptible cultivars, larvae of $P$. destructor can fed in spaces between rows with rod-shaped masses, however, in resistant ones, dense and grainy shapes ranging from round to oblong did not provide suitable spaces for P. destructor feeding (Miller et al., 1960).

Lower levels of sugarcane scale Melanaspis glomerata (Green) (Homoptera: Coccidae) infestation were recovered on sugarcane clones with higher numbers of silica cells in the wax band of the inter-node (Agarwal, 1969). Hindered of oviposition rates by the Argentine stem weevil Listronotus bonariensis Kuschel (Coleoptera: Curculionidae) was positively correlated with high densities of silica deposits (inclusive of trichomes) in the sheath epidermis of ryegrass cultivars (Barker, 1989). Greater protection in resistant sugarcane cultivars to the African sugarcane borer Eldana saccharina Walker (Lepidoptera: 
Pyralidae) was due to silica bodies scattered over the pseudostem than theses deposited in discrete rows in susceptible cultivars (Kvedaras et al., 2007b). Also, the authors observed that small increases in plant silicon fertilization led to significantly reduce the number of larvae found.

\section{Silicon in controlling insect pests}

The association between silicon treatment and reduced insect damage has been the object of several studies on plant-insect interactions (Ma, 2004; Reynolds et al., 2009; Liang et al., 2015a). Silicon application has been shown to decrease development, reproductive period, longevity, and fecundity of insect pests (Reynolds et al., 2009; Liang et al., 2015a).

Traditionally, two sources of silicon have been used to deliver silicon to the plant in deficient agricultural soils: solid treatment incorporated into the soil in the form of calcium silicate $\left(\mathrm{Ca}_{2} \mathrm{SiO}_{4}\right)$ and silicate solutions applied as a soil drench or as a foliar spray in the form of sodium silicate $\left(\mathrm{Na}_{2} \mathrm{SiO}_{3}\right)$ (Savant et al., 1999; Reynolds et al., 2009; Heckman, 2013). The ideal characteristics considered for a good source of silica to pest insect control could be presented as follows: high concentration of soluble silicon available to plants, physical properties that will facilitate storage ability, easy to mechanical application, uncontaminated with heavy metals, and low cost (Reynolds et al., 2009; Heckman, 2013).

Furthermore, it has been demonstrated that the elicitors (biocompatible molecules) can exhibit remarkable resistance against insect pest damage in combination with silicon, for example, the insect growth regulator lufenuron in affecting the preference of the fall armyworm Spodoptera frugiperda Smith (Lepidoptera: Noctuidae) on maize (Neri et al., 2005), fungicide acibenzolar-S-methyl (ASM) in reducing the larval period and pupal weight and increased the pupal period of the leaf-worm Alabama argillacea Hubner (Lepidoptera: Noctuidae) (Tomquelski et al., 2007) on cotton, ASM in reducing weight of the sunflower caterpillar Chlosyne lacinia saundersii Doubleday and Hewitson (Lepidoptera: Nymphalidae) larvae on sunflower (Assis et al., 2015), and systemic insecticide imidacloprid in decreasing the mealy-bug third-instar Phenacoccus solenopsis Tinsley (Hemiptera: Pseudococcidae) nymphs and adult females on Portulaca grandiflora plants (Huang et al., 2014).

In spite of the wide difference between borers and sap-feeding pest insects regarding reproductive and feeding behaviour on crops of great economic importance, silicon

can improve plant resistance to insect attack and infestation for the two guilds (Reynolds et al., 2009, 2016; Liang et al., 2015a), and it plays a role in pest resistance in most cultivated crops (Reynolds et al., 2009, 2016; Liang et al., 2015a).

\section{Wheat (Triticum aestivum L.) resistance to pest infestation}

Evidence indicated that the resistance of different varieties of plant to the Hessian fly $P$. destructor is due to high silica content (McColloch and Salmon, 1923). Increased silicon content in plant stems reduced largely damage caused by the larvae of Hessian fly, and greater protection was observed in susceptible cultivars treated with a solution containing sodium silicate (Miller et al., 1960). 
Foliar $\mathrm{Na}_{2} \mathrm{Si}_{2}$ (1\% concentration) treatment increased resistance in plants to two important aphids, the rose-grain aphid Metopolophium dirhodum Walker (Hemiptera: Aphididae) and the English grain aphid Sitobion avenae Fabricius (Hemiptera: Aphididae) through enhancing silicon solubility within the leaves (Hanisch, 1981). Dias et al. (2014) observed that reduced fecundity, reproductive period, longevity, intrinsic rate of increase, and net reproductive rate of apterous $S$. avenae was due to induction of antibiosis resistance in plants treated with silicon.

Positive effects of silicon treatment were evident as reduced preference, longevity and fecundity rates, nymph production and feeding times by nymphs of green bug Schizaphis graminum (Rondani) (Hemiptera: Aphididae) (Gomes et al., 2005; Goussain et al., 2005; Costa et al., 2011).

\section{Maize (Zea mays L.) resistance to pest infestation}

Enhanced plant resistance by reducing the stalk-borer Chilo zonellus Swinhoe (Lepidoptera: Pyralidae) damage was due to increased silicon rates (Sharma and Chatterji, 1972). Higher levels of soluble silicon in the sheath and collar tissue enhanced plant resistance to the second generation of the European corn borer Ostrinia nubilalis Hubner (Lepidoptera: Pyralidae) (Rojanaridpiched et al., 1984). Setamou et al. (1993) noted that increased sodium metasilicate fertilization reduced larval stem borer Sesamia calamistis Hampson (Lepidoptera: Noctuidae) survival from $26.0 \%$ (control) to $4.0 \%$ at $0.56 \mathrm{~g} \mathrm{Si} / \mathrm{plant}$.

High silicon application increased mortality levels of the fall armyworm Spodoptera frugiperda Smith (Lepidoptera: Noctuidae) (Goussain et al., 2002). By using artificial diets containing silica at different concentrations, Horng and Chu (1990) found that the mortality of larvae and pupae of the Asian corn borer Ostrinia furnacalis Guenee (Lepidoptera: Crambidae) increased as silica content increased, and they observed that the fecundity, net reproductive rate and intrinsic rate of increase were negatively correlated with diet silica content. Almeida et al. (2015) found that the silicon fertilization contributed to an increase in the induction of non-preference of corn leaf aphid Rhopalosiphum maidis Fitch (Hemiptera: Aphididae).

\section{Rice (Oryza sativa L.) resistance to pest infestation}

Sasamoto (1961) found that the increase in silicon content of plants grown in silicon supplied soils decreased their susceptibility to the Asian rice stem borer Chillo suppressalis Walker (Lepidoptera: Crambidae). High silicon application reduced the bore and faeces rates of $C$. suppressalis larvae in vitro (Ma and Takahashi, 2002). Moreover, Hou and Han (2010) noted that silicon treatment decreased penetration $C$. suppressalis, weight gain, and stem damage.

High silicon deposits in stems of resistant varieties inhibited larvae attack of the yellow stem borer Scirpophaga incertulas Walker (Lepidoptera: Pyralidae) (Panda et al., 1975). Growth inhibition of the brown plant-hopper Nilaparvata lugens Stal (Hemiptera: Delphacidae) was due to silicic acid at the concentration $<0.01 \mathrm{mg} \mathrm{Si} / \mathrm{ml}$ (Yoshihara and Sogawa, 1979). High silicon content in plant lines had significant antibiotic and an- 
tixenotic effects on $N$. lugens by reducing survival rate, settled insect number, fertility and honeydew excretion (He et al., 2015). Kin and Heinrichs (1982) observed that silicon application in seedlings reduced the adulthood level of nymphs of the white-backed plant-hopper Sogatella furcifera Horvath (Hemiptera: Delphacidae) and increased the male proportion.

High silicon content decreased the rates for bored stem and number of living larvae per plant of the African striped borer Chilo zacconius Bleszynski (Lepidoptera: Pyralidae) (Ukwungwu, 1990). The resistance of 11 rice cultivars to the stem-borer Chilo agamemnon Bleszynski (Lepidoptera: Crambidae) and to the leaf miner Hydrellia prosternalis Deeming (Diptera: Ephydridae) increased due to higher levels of silicon application (Soliman et al., 1997).

Silicon concentration at $373 \mathrm{mg} \mathrm{g}^{-1}$ dry weight in leaves increased plant resistance to the green rice caterpillar Naranga aenescens Moore (Lepidoptera: Noctuidae) and leaf rice roller Cnaphalocrocis medinalis (Guenee) (Lepidoptera: Pyralidae) (Nakata et al., 2008). Moreover, low and high silicon levels applied to susceptible variety reduced larval survival rate and pupation rate in the C. medinalis (Han et al., 2015).

\section{Sugarcane (Saccharum officinarum L.) resistance to pest infestation}

Silicon increased plant resistance and decreased borer recovery, against the sugarcane shoot-borer Chilo infuscatelus Snell (Lepidoptera: Crambidae) (Rao, 1967), the sugarcane top borer Scirpophaga excerptalis Walker (Lepidoptera: Crambidae) (Gupta et al., 1992), and the sugarcane stem borer Diatraea saccharalis Fabricius (Lepidoptera: Crambidae) (Anderson and Sosa, 2001). Pan et al. (1979) also noted a reduction in the incidence of borer damage in silicon-treated plants by stem borers as compared with untreated control, following application of bagasse furnace ash and silica slag.

In both field and greenhouse trials, the silicon treatment significantly increased plant resistance by reducing damage, larval weight, and numbers of borers recovered from stalks to the African sugarcane borer E. saccharina (Keeping and Meyer, 2002; Meyer and Keeping, 2005; Kvedaras and Keeping 2007). Increased nymphal mortality and decreased the longevity of males and females of the sugarcane spittlebug Mahanarva fimbriolata Stal (Hemiptera: Cercopidae) was due to high silicon absorption and accumulation (Korndorfer et al., 2011).

\section{Silicon induced resistance of other crops to pest infestation}

Sodium silicate fertilization to sorghum affected preference and reduced feeding and number of nymphs produced by the green bug S. graminum (Carvalho et al., 1999). Singh et al. (1993) found that the incidence of the sweet potato weevil Cylas formicarius Fabricius (Coleoptera: Curculionidae) was negatively correlated with silica content of all the tested plant cultivars. Calcium silicate application in cucumber plants decreased the whitefly Bemisia tabaci Gennadius (Hemiptera: Aleyrodidae) population by reducing oviposition and increasing cycle length and mortality at the nymphal stage (Correa et al., 
2005). Silicon fertilization to potato reduced preference and growth rates of green peach aphid Myzus persicae Sulzer (Hemiptera: Aphididae) (Gomes et al., 2008).

Reduced potato leaf palatability due to silicic acid foliar or soil-treatments reduced feeding injury of the cucurbit beetle Diabrotica speciosa Germar (Coleoptera: Chrysomelidae) (Gomes et al., 2009; Assis et al., 2012). Ferreira et al. (2011) determined that silicon combined with soybean plant caused significantly mortality in whitefly $B$. tabaci nymphs.

A single silicon spraying to peanut governed a greater protection by reducing the number of the silvering thrips Enneothrips flavens Moulton (Thysanoptera: Thripidae) adults and nymphs (Dalastra et al., 2011). Assis et al. (2013) reported that the levels of injured leaves and leaf area consumption of the sunflower caterpillar $C$. lacinia saundersii were decreased due to silicon application combined with artificial mechanical injuries which negatively affect leaf palatability. Calcium silicate concentration at $50 \mathrm{mg} \mathrm{L}^{-1} \mathrm{re}-$ duced the occurrence of Mediterranean fruit fly Ceratitis capitata Wiedemann (Diptera: Tephritidae) injury symptoms in lemon plants (Mditshwa et al., 2013).

\section{Mechanisms of silicon-enhanced resistance}

Regardless of the numerous scientific studies about silicon effects on insect pest infestation, the characteristics, spectrum of efficacy and mode of action of silicon is not entirely understood (Ma 2004; Reynolds et al., 2009, 2016; Liang et al., 2015a). Under optimum conditions, silicon does not affect plant growth or development (Ma and Yamaji, 2006). However, beneficial and useful effects only manifest under stress conditions (Ma 2004; Liang et al., 2007, 2015b). The mechanisms by which silicon is likely to affect insect pest development, reproductive period, longevity, and fecundity characteristics are not fully understood and need further research (Reynolds et al., 2009, 2016; Liang et al., 2015a). Generally, the effect of silicon on resistance of plants to insect pest is considered to be due to either a deposition of silicon on cell walls acting as a mechanical barrier difficult the insect-pests attack, or biochemical changes related to plant defense (Reynolds et al., 2009, 2016; Liang et al., 2015a).

\section{Physical defense}

The hypothesis of silicon-physical enhanced resistance is based on two mechanisms by which silicon deposition acts as a physical barrier; however, both currently lack good experimental support (Reynolds et al., 2009; Liang et al., 2015a). First, silicon decreases the efficiency with which insect pests can digest plant leaves. Second, enhanced hardness and abrasiveness of plant tissues due to silicon may increase the wear on insect pest mouthparts, both of which could potentially impact on insect pest performance. It seems that the physical defense due to silica deposition, mainly as opaline phytoliths in association with cell walls, is the most widely accepted mechanism for the action of silicon in increasing plant resistance to insect pest infestation (Reynolds et al., 2009; Liang et al., 2015a). 


\section{Silicon reduces digestibility of plant tissues}

Increased silicon plant content via silicate fertilization and/or silicon-rich diets may decrease insect pest growth and performance rates by reducing: (1) the consumption, (2) the efficiency of food utilization by decreasing the ingestion of sufficient quantities of nutrient and water, (3) the digestive efficiency by decreasing the conversion of ingested food to body mass, (4) by altering and deterring insect pest feeding, and (5) by counteracting the effects of high plant nitrogen rates in promoting insect pest performance (Reynolds et al., 2009, 2016; Liang et al., 2015a).

Chu and Horng (1991) observed that increased hardness level in stems to Asian corn borer $O$. furnacalis was due to calcium silicate slag applied to corn plants, and tissue hardness rates decreased the consumption of the leaves by pest, indicating that leaf hardness and abrasiveness due to high silica deposition may be associated with the resistance to the borer. The $O$. furnacalis larvae fed on artificial diets containing high silicon content resulted in increasing mortality of larvae and pupae, prolonging pre-oviposition period and shortening the oviposition period (Horng and Chu, 1990).

Salim and Saxena (1992) found that increased levels of silicon content in susceptible rice cultivars reduced plant consumption by $S$. furcifera, in addition to decreased number of nymphs becoming adults, adult longevity, female fecundity, growth and population increases. The rate of both conversion ingested food into body mass, and the amount of nitrogen absorbed from their food of the African armyworm Spodoptera exempta Walker (Lepidoptera: Noctuidae) was decreased due to silicon-rich diets (Massey and Hartley, 2009).

Increased leaf abrasiveness due to silicon uptake altered and deterred the desert locust Schistocerca gregaria Forskal (Orthoptera: Acrididae) and S. exempta fed on grass species (Massey et al., 2006). Under free-choice conditions, Chu and Horng (1991) reported reduced growth rates of Asian corn borer for silicon-treated plants but enhanced preference criteria for high-nitrogen-treated plants. Meyer and Keeping (2005) and Keeping et al. (2014) showed that silicon application via soil treatment can diminish the increased infestations of $E$. saccharina due to nitrogen fertilization. Moreover, rice plants received higher dose of silicon $600 \mathrm{~kg} / \mathrm{ha}$ in combination with nitrogen fertilization recorded the lower incidence of yellow stem borer, gall midge Orseolia oryzae Wood-Mason (Diptera: Cecidomyiidae), brown plant hopper and green leaf hopper Nephotetticx virescens Distant (Hemiptera: Cicadellidae) (Rajamani et al., 2013), thus ensuring that recommended rates of nitrogen could be applied for sugarcane and rice plants without limiting crop productivity. However, Keeping et al. (2014) found that silicon treatments with high nitrogen treatments did not significantly influence the exotic sugarcane thrips Fulmekiola serrata Kobus (Thysanoptera: Thripidae) infestation.

Nil effect of silicon artificial diets on insect pest has also been highlighted. Stanley et al. (2014) found that silicon artificial diets did not reduce larval growth for two cotton bollworms Helicoverpa armigera Hubner and $H$. punctigera Wallengren (Lepidoptera: Noctuidae), so results of this test do not corroborate the hypothesis that silicon is directly antibiotic to Helicoverpa spp. via ingestion (Stanley et al., 2014). Silicon applied to tomato leaves caused a detachment of the basal membrane in the midgut epithelium in 
larvae of the tomato leaf-miner Tuta absoluta Meyrick (Lepidoptera: Gelechiidae) (dos Santos et al., 2015).

\section{Silicon causes mandible wear}

In larval Lepidoptera, mandible wear due to increased hardness and abrasiveness of silicon in plant cell walls was correlated with reduced preference rates, so that feeding ability is compromised and impaired growth or starvation ensues (Raupp, 1985; Massey and Hartley, 2009). Mandibles replacement at each moult makes silicon effect is indefinite. However, increased mandible wear forced larvae fed on plants high in silicon to moult sooner than usual, which could be associated with decreased body weight in insect pests. Several studies have indicated augmented mandible wear in lepidopteran larvae fed on plant cultivars with high silicon content (Reynolds et al., 2009, 2016; Liang et al., 2015a).

Djamin and Pathak (1967) observed significant mandible damage in larvae of the stem-borer $C$. supressalis fed on rice plants with incensed silicon content. Artificial diets containing silicon at elevated concentrations caused high mandible wear in leaf rice roller larvae C. medinalis (Ramachandran and Khan, 1991). Goussain et al. (2002) reported that the applications of sodium silicate to corn plants caused wearing out in the incisory region of the mandibles of fall armyworm $S$. frugiperda. Rapid increasing in mandible wear of S. exempta was due to silicon fertilization to grass species (Massey and Hartley, 2009).

Negligible effect of silicon amendment on mandible wear has been shown in some studies. Calcium silicate fertilization to 'Penncross' creeping bentgrass caused a little mandible wear of the black cutworm, Agrotis ipsilon Hufnagel (Lepidoptera: Noctuidae) and the root-feeding masked chafer grubs, Cyclocephala spp. (Redmond and Potter, 2007). Kvedaras et al. (2009) observed that the sugarcane cultivars treated with silicon caused a slight mandible wear in E. saccharina larvae.

\section{Biochemical defense}

The soluble silicon in plant tissue may induce plant defense against insect pest attack via (1) increased activity of defensive enzymes, such as polyphenoloxidase, peroxidase, phenylalanine ammonia-lyase in leaves, and (2) increased production of defensive chemicals, such as tannins, lignin and phenols. Biochemical changes due to silicon absorption could diminish the quality of phloem sap and affect pest insect development criteria (Reynolds et al., 2009, 2016; Liang et al., 2015a). Many biochemical mechanisms of defense to insect pest infestation are shared with those against plant pathogenic fungi (Van Bockhaven et al., 2013; Sakr 2016b). Regarding all studies demonstrating the positive effect of silicon on insect pest preference, it is evident that the role of biochemical resistance was less important than physical defense (Reynolds et al., 2009, 2016; Liang et al., 2015a). Further research should be carried out on several pest insects to reveal the importance of biochemical defense to reduce insect pest damage.

Induced resistance to the green bug $S$. germanium generated by biochemical changes because of the absorbed silicon by wheat plants may be of greater importance than physical impediment, as the stylet eventually did reach phloem resulting in reduction 
of probing time (Goussain et al., 2005). In the same association between S. germanium and wheat plants, increased activities of three defensive enzymes, polyphenoloxidase, peroxidase, and phenylalanine ammonia-lyase due to soluble silicon negatively affected pest growth and preference (Gomes et al., 2005). Indeed, induced resistance to the whitefly B. tabaci in cucumber due to silicon absorbed by plants was expressed by synthesis of defense chemicals that cause stylet withdraw (Correa et al., 2005).

Induced resistance by way of defensive chemicals including silica and phenols due to organic fertilizers applied to eggplant plants reduced preference and growth rates, feeding rate, oviposition, longevity and population buildup and prolonged the nymphal duration of eggplant insect pests (Zadda et al., 2007). Silicon fertilization increased lignin and tannins concentration in the leaves of potato plants to aphid $M$. persicae attack, and it seems that the silicon acted as a resistance inducer to insect pest by reducing fecundity and the rate of population growth (Gomes et al., 2008). da Silva et al. (2010) showed that the spray fertilization with solution of silicic acid acted as inducer of the tannin synthesis in the potato leaves and consequently, decreased the number of aphid and leaves injuries caused by the leaf-beetle Diabrotica spp. (Coleoptera: Chrysomelidae) and the number of mined leaves by leaf-miners Liriomyza spp. (Diptera: Agromyzidae).

Increased peroxidase and polyphenoloxidase activity in seedlings of mandarin orange due to potassium silicate application reduced development of citrus black-fly Aleurocanthus woglumi Ashby (Homoptera: Aleyrodidae); and both factors: feeding time of A. woglumi and silicon concentration induced synthesis of plant defense compounds (Vieira et al., 2016).

\section{Indirect effects of silicon nutrition}

Several indirect effects of silicon may be caused by delaying insect pest establishment and thus an increased probability of exposure to natural enemies, unfavorable climatic conditions or control procedure that target exposed insects (Reynolds et al., 2009, 2016).

The accumulation of silicon in sugarcane plants increases the difficulty of penetration by the African sugarcane borer E. saccharina, and it augments the exposure time of young larvae to natural enemies, abiotic conditions, or control practices that target such larvae (Kvedaras and Keeping, 2007). Also, Kvedaras et al. (2007a) observed an interaction between silicon-enhanced sugarcane resistance to African sugarcane borer E. saccharina and water stress. In sugarcane plants treated with silicon, water-stressed cane showed more reduction in borer numbers and stalk damage than non-stressed cane, particularly for susceptible cultivars (Kvedaras et al., 2007a). These results are in accordance with other studies, where lower fungal disease intensity in the silicon-treated plants is more obvious under conditions of abiotic stress than non-stressed conditions (Ma, 2004; Liang et al., 2015b). Such observation hypothesis shows that silicate fertilization could augment insect pest resistance of plants exposed to a multitude of a range of abiotic stresses, including salinity stress and heavy metal toxicity.

Feeding damage decrease for the sugarcane borer $D$. saccharalis due to silicon application increased exposure to unfavorable climatic conditions and natural enemies 
arising from reduced boring success (Sidhu et al., 2013), and this provides evidence that silicon fertilization may contribute to the management of this pest.

Augmentation of plant resistance due to silicon application could be associated with increased production of plant hormones including jasmonate (JA) and salicylate (SA) (Reynolds et al., 2009, 2016). When damaged with insect pest attack, many plants released hormones attracting beneficial natural enemies into silicon-treated plants (Dicke et al., 2003; Reynolds et al., 2009, 2016). The application of potassium silicate with a subsequent Helicoverpa armigera Hubner (Lepidoptera: Noctuidae) larvae infestation augmented cucumber plants' ability to mount an induced response by attracting natural enemy, adult predator Dicranolaius bellulus Guerin-Meneville (Coleoptera: Melyridae) (Kvedaras et al., 2010).

Amplification of JA mediated defense responses in rice to $C$. medinalis was due to silicon application (Ye et al., 2013), and the authors suggest that silicon acted as a priming agent in pathogenesis-mediated host defense signaling pathway. Increased silicon content in grapevine plants infected by the light brown apple moth Epiphyas postvittana (Walker) (Lepidoptera: Tortricidae) significantly attracted the predatory beetle $D i$ cranolaius bellulus (Guerin-Meneville) (Coleoptera: Melyridae) (Reynolds et al., 2014). By using solid-phase micro-extraction (SPME)/gas chromatography-mass spectrometry (GC-MS) analysis, the grapevine plant infected with the Australian grapevine moth Phalaenoides glycinae (Lewin) (Lepidoptera: Noctuidae) released seven volatile compounds, and higher amounts of $n$-heptadecane were detected only in plants treated with silicon (Reynolds et al., 2014).

\section{Cases of non-effect of silicon on plant resistance to insect pests}

There are studies on the failure of silicon to reduce pest performance and growth for the two main insect feeding guilds (Reynolds et al., 2009). However, no convincing evidence has been proposed in identifying any trend in how silicon plant content may differentially affect insect pests (Keeping and Kvedaras, 2008). Regarding some plant species, it seems that the insufficient accumulation of quantities of silicon do not protect them against pest insect attack (see the previous section on agricultural importance of silicon in plants).

Silicon content of soybeans had no significant effect on pupal weight of the Mexican bean beetle Epilachna varivestis Mulsant (Coleoptera: Coccinellidae) (Mebrahtu et al., 1988). In rice plants, no significant relationship has been established between silicon content and both: percentage white-heads and percentage dead-hearts caused by stem borers (mainly C. suppressalis) (Sunio et al., 2000). Corn plants treated with sodium silicate did not affect preference and growth rates of the corn leaf aphid Rhopalosiphum maidis (Fitch) (Hemiptera: Aphididae) compared to the control without silicon (Goussain, 2001).

Potassium silicate application at a concentration up to $800 \mathrm{ppm}$ to poinsettia plants did not provide protection to greenhouse whitefly Trialeurodes vaporariorum Westwood 
(Hemiptera: Aleyrodidae) developing on leaves (Hogendorp et al., 2010). On Zinnia elegans plants, pre-reproductive period and survivorship of the green peach aphid Myzus persicae Sulzer (Hemiptera: Aphididae) was not affected by potassium silicate solutions (Ranger et al., 2009). Potassium silicate solutions did not alter the proportion of pepper leaves that sustained chilli thrips Scirtothrips dorsalis Hood (Thysanoptera: Thripidae) damage, insufficient silicon accumulation level in leaf tissues did not govern protect against pest insect infestation (Dogramaci et al., 2013).

The probing behavior of the citrus mealy-bug Planococcus citri Risso (Hemiptera: Pseudococcidae) was not affected by soil calcium silicate treatment to coffee plants (Santa-Cecilia et al., 2014). Amado and Rizental (2015) found that the silicon application caused no significant differences for population size of cotton aphid Aphis gossypii (Hemiptera: Aphididae) and whitefly B. tabaci on cotton plants.

\section{Conclusion}

Silicon-induced plant resistance to insect pest infestation via physical and biochemical mechanisms represents a critical strategy, which provides an active and long lasting solution to maintain low levels of insect pest populations, and primary reduces yield losses. Enhanced resistance to insect attacks and infestation of lepidopteran borers and sap-feeding insects following artificial silicon applications have been observed in a wide variety of plant species. Physical defense due to silica deposition is more acceptable in explaining plant resistance to insect pests than a biochemical resistance because of silicon absorption. New approaches to understand silicon biochemical effects on plants and insect pests should be carried on induced resistance by silicon. Nil effect of silicon application against some pest insects, including the two main insect feeding guilds, is not limited to low silicon-accumulators, but it has been noticed in high accumulators, too. Silicon could be potentially of great benefit for non-insecticide pest management. Complete understanding of the biological role of silicon in plants improves the effective use of silicon to increase crop productivity and enhance insect pest resistance.

\section{Acknowledgements}

I would like to thank the Director General of AECS and the Head of the Agriculture Department for their continuous support throughout this work.

\section{Literature}

Agarwal, R. A. (1969): Morphological characteristics of sugarcane and insect resistance. Entomol. Exp. Appl. 12, 767-776.

Almeida, A. C. de Sousa., Silva, L. P., de Jesus, F. G., Nogueira, L., Neto, M. de Sousa. and da Cunha, P. C. R. (2015): Effects of the resistance inducers in attractiveness to aphid Rhopalosiphum maidis (Fitch, 1856) (Hemiptera: Aphididae) in corn. Rev. Agrar. 8, 23-29. 
Amado, D. and Rizental, M. (2015): Silício como indutor de resistência a Aphis gossypii (Hemiptera: Aphididae) e Bemisia tabaci (Hemiptera: Aleyrodidae) em algodoeiro. Rev. Connection line 12, 106-112.

Anderson, D. L. and Sosa, O. Jr. (2001): Effect of silicon on expression of resistance to sugarcane borer (Diatraea saccharalis). J. Am. Soc. Sugar Cane Tech. 21, 43-50.

Assis, F. A., Moraes, J. C., Silveira, L. C. P., Francoso, J., Nascimento, A. M. and Antunes, C. S. (2012): Inducers of resistance in potato and its effects on defoliators and predatory insects. Rev. Colomb. Entomol. 38, 30-34.

Assis, F. A., Moraes, J. C., Auad, A. M. and Coelho, M. (2013): The effects of foliar spray application of silicon on plant damage levels and components of larval biology of the pest butterfly Chlosyne lacinia saundersii (Nymphalidae). Int. J. Pest Manage. 59, 128-134.

Assis, F. A., Moraes, J. C., Assis, G. A. and Parolin, F. J. T. (2015): Induction of caterpillar resistance in sunflower using silicon and Acibenzolar-S-Methyl. J. Agr. Sci. Tech. 17, 543-550.

Aston, M. J. and Jones, M. M. (1976): Study of the transpirational surfaces of Avena sterilis L. var. Algerian leaves using monosilicic acid as a tracer for water movement. Planta 130, 121-129.

Barker, G. M. (1989): Grass host preferences of Listronotus bonariensis (Coleoptera: Curculionidae). J. Econ. Entomol 82, 1807-1816.

Carvalho, S. P., Moraes, J. C. and Carvalho, J. G. (1999): Silica effect on the resistance of Sorghum bicolor (L.) Moench to the greenbug Schizaphis graminum (Rond.) (Homoptera: Aphididae). An. Soc. Entomol. Bras. 28, 505-510.

Chu, Y. I. and Horng, S. B. (1991): Infestation and reproduction of Asia corn borer on slag-treated corn plants. Chin. J. Entomol. 11, 19-24.

Correa, R. S., Moraes, J. C., Auad, A. M. and Carvalho, G. A. (2005): Silicon and acibenzolar-S-methyl as resistance inducers in cucumber, against the whitefly Bemisia tabaci (Gennadius) (Hemiptera: Aleyrodidae) biotype B. Neotrop. Entomol. 34, 429-433.

Costa, R. R., Moraes, J. C. and Costa, R. R. (2011): Feeding behaviour of the greenbug Schizaphis graminum on wheat plants treated with imidacloprid and/or silicon. J. Appl. Entomol. 135, 115-120.

da Silva, V. F., Moraes, J. C. and Melo, B. A. (2010): Sources of silicon in the induction of resistance for pest insects and in the development of potato enhancement. Rev. Bras. Agroecologia 5, 149-156.

Dalastra, C., Campos, A. R., Fernandes, F. M., Gustavo, M. L. and Campos, Z. R. (2011): Silicon as a resistance inducer controlling the silvering thrips Enneothrips flavens Moulton, 1941 (Thysanoptera: Thripidae) and its effects on peanut yield. Cienc. Agrotec. 35, 531-538.

Denholm, I. and Rowland, M. W. (1992): Tactics for managing pesticide resistance in arthropods: theory and practice. Annu. Rev. Entomol. 37, 91-112.

Dias, P. A. S., Sampaio, M. V., Rodrigues, M. P., Korndorfer, A. P., Oliveira, R. S., Ferreira, S. E. and Korndorfer, G. H. (2014): Induction of resistance by silicon in wheat plants to alate and apterous morphs of Sitobion avenae (Hemiptera: Aphididae). Environ. Entomol. 43, 949-956.

Dicke, M., van Poecke, R. M. P. and de Boer, J. G. (2003): Inducible indirect defence of plants: from mechanisms to ecological functions. Basic Appl. Ecol. 4, 27-42.

Djamin, A. and Pathak, M. D. (1967): Role of silica in resistance to Asiatic rice borer, Chilo suppressalis Walker, in rice varieties. J. Econ. Entomol. 60, 347-351.

Dogramaci, M., Arthurs, S. P., Chen, J. and Osborne, L. (2013): Silicon applications have minimal effects on Scirtothrips dorsalis (Thysanoptera: Thripidae) populations on pepper plant, Capsicum annum L. Fla. Entomol. 96, 48-54.

dos Santos, M. C., Junqueira, R. A. M., Mendes de Sa, V. G., Zanuncio, J. C. and Serrao, J. E. (2015): Effect of silicon on the morphology of the midgut and mandible of tomato leafminer Tuta absoluta (Lepidoptera: Gelechiidae) larvae. Invertebrate Surviv. J. 12, 158-165.

Epstein, E. (1994): The anomaly of silicon in plant biology. Proc. Natl Acad. Sci. USA 91, 11-17.

Epstein, E. (1999): Silicon. Annu. Rev. Plant. Biol. 50, 641-664.

Epstein, E. (2009): Silicon: Its manifold roles in plants. Ann. Appl. Biol. 155, 155-160. 
Ferreira, R. S., Moraes, J. C. and Antunes, C. S. (2011): Silicon influence on resistance induction against Bemisia tabaci biotype B (Genn.) (Hemiptera: Aleyrodidae) and on vegetative development in two soybean cultivars. Neotrop. Entomol. 40, 495-500.

Gomes, F. B., Moraes, J. C., Santos, C. D. and Goussain, M. M. (2005): Resistance induction in wheat plants by silicon and aphids. Sci. Agric. 62, 547-551.

Gomes, F. B., Moraes, J. C. and Antunes, C. S. (2008): Use of silicon as inductor of the resistance in potato to Myzus persicae (Sulzer) (Hemiptera: Aphididae). Neotrop. Entomol. 37, 185-190.

Gomes, F. B., Moraes, J. C. and Neri, D. K. P. (2009): Fertilization with silicon as resistance factor to pest insects and promoter of productivity in the potato crop in an organic system. Cienc. Agrotec. 33, 18-23.

Goussain, M. M. (2001): Efeito da aplicação do silício em plantas de milho no desenvolvimento biológico da lagarta-do-cartucho Spodoptera frugiperda (J. E. Smith) e do pulgão-da-folha Rhopalosiphum maidis (Fitch, 1856) (Hemiptera: Aphididae). [Dissertation]. [Lavras: UFLA], Lavras University.

Goussain, M. M., Moraes, J. C., Carvalho, J. G., Nogueira, N. L. and Rossi, M. L. (2002): Effect of silicon application on corn plants upon the biological development of the fall armyworm Spodoptera frugiperda (J. E. Smith) (Lepidoptera: Noctuidae). Neotrop. Entomol. 31, 305-310.

Goussain, M. M., Prado, E. and Moraes, J. C. (2005): Effect of silicon applied to wheat plants on the biology and probing behaviour of the greenbug Schizaphis graminum (Rond.) (Hemiptera: Aphididae). Neotrop. Entomol. 34, 807-813.

Gupta, S. C., Yazdani, S. S., Hameed, S. F. and Agarwal, M. L. (1992): Effect of potash application on incidence of Scirpophaga excerptalis Walker in sugarcane. J. Insect Sci. 5, 97-98.

Han, Y., Lei, W., Wen, L. and Hou, M. (2015): Silicon-mediated resistance in a susceptible rice variety to the rice leaf folder, Cnaphalocrocis medinalis Guenée (Lepidoptera: Pyralidae). PLoS One 10, e0120557.

Hanisch, H. C. (1981): Die Populationsentwicklung von Getreideblattlausen an Weizenpflanzen nach verschieden hoher Stickstoffdungung und vorbeugender Applikation von Kieselsaure zur Wirtspflanze. Mitt. Dtsch. Ges. Allg. Angew. Entomol. 3, 308-311.

He, W., Yang, M., Li, Z., Qiu, J., Liu, F. and Qu, X. (2015): High levels of silicon provided as a nutrient in hydroponic culture enhances rice plant resistance to brown planthopper. Crop Prot. 67, 20-25.

Heckman, J. (2013): Silicon: A beneficial substance. Better Crops 97, 14-16.

Hogendorp, B. K., Cloyd, R. A., Xu, C. G. and Swiader, J. M. (2010): Effect of silicon-based fertilizer applications on nymphal development and adult emergence of the greenhouse whitefly (Hemiptera: Aleyrodidae) feeding on poinsettia. J. Entomol. Sci. 45, 150-169.

Horng, S. B. and Chu, Y. I. (1990): Development and reproduction of Asian corn borer (Ostrinia furnacalis Guenee) fed on artificial diet containing silica. Chin. J. Entomol. 10, 325-335.

Hou, M. L. and Han, Y. Q. (2010): Si-mediated rice plant resistance to the Asiatic rice borer: effects of silicon amendment and rice varietal resistance. J. Econ. Entomol. 103, 1412-1419.

Huang, J., Zhang, J., Wang, D., Zhang, L., Xu, Y. and Li, M. (2014): Do organic silicon and imidacloprid synergistically induce toxicity to the new invasive mealybug Phenacoccus solenopsis Tinsley on Portulaca grandiflora plants? Turk. J. Agric. For. 38, 207-213.

Jones, L. and Handreck, K. (1967): Silica in soils, plants, and animals. Adv. Agron. 19, 107-149.

Keeping, M. G. and Meyer, J. H. (2002): Calcium silicate enhances resistance of sugarcane to the African stalk borer Eldana saccharina Walker (Lepidoptera: Pyralidae). Agric. For. Entomol. 4, 265-274.

Keeping, M. G. and Kvedaras, O. L. (2008): Silicon as a plant defence against insect herbivory: response to Massey, Ennos and Hartley. J. Anim. Ecol. 77, 631-633.

Keeping, M. G., Miles, N. and Sewpersad, C. (2014): Silicon reduces impact of plant nitrogen in promoting stalk borer (Eldana saccharina) but not sugarcane thrips (Fulmekiola serrata) infestations in sugarcane. Front. Plant Sci. 5, 289.

Kin, H. S. and Heinrichs, E. A. (1982): Effects of silica level on whitebacked planthopper. Int. Rice Res. New. 7,17 .

Korndorfer, A. P., Grisoto, E. and Vendramim, J. D. (2011): Induction of insect plant resistance to the spittlebug Mahanarva fimbriolata Stål (Hemiptera: Cercopidae) in sugarcane by silicon application. Neotrop. Entomol. 40, 387-392. 
Kvedaras, O. L. and Keeping, M. G. (2007): Silicon impedes stalk penetration by the borer Eldana saccharina in sugarcane. Entomol. Exp. Appl. 125, 103-110.

Kvedaras, O. L., Keeping, M. G., Goebel, F. R. and Byrne, M. J. (2007a): Water stress augments silicon-mediated resistance of susceptible sugarcane cultivars to the stalk borer Eldana saccharina (Lepidoptera: Pyralidae). Bull. Entomol. Res. 97, 175-183.

Kvedaras, O. L., Keeping, M. G., Goebel, F. R. and Byrne, M. J. (2007b): Larval performance of the pyralid borer Eldana saccharina Walker and stalk damage in sugarcane: influence of plant silicon, cultivar and feeding site. Int. J. Pest Manag. 53, 183-194.

Kvedaras, O. L., Byrne, M. J., Coombes, N. E. and Keeping, M. G. (2009): Influence of plant silicon and sugarcane cultivar on mandibular wear in the stalk borer Eldana saccharina. Agric. For. Entomol. 11, 301-306.

Kvedaras, O. L., An, M., Choi, Y. S. and Gurr, G. M. (2010): Silicon enhances natural enemy attraction and biological control through induced plant defences. Bull. Entomol. Res. 100, 367-371.

Liang, Y., Sun, W., Zhu, Y. G. and Christie, P. (2007): Mechanisms of silicon-mediated alleviation of abiotic stresses in higher plants: A review. Environ. Pollut. 147, 422-428.

Liang, Y., Nikolic, M., Belanger, R., Gong, H. and Song, A. (2015a): Silicon and insect pest resistance. In: Y. Liang et al. (eds): Silicon in Agriculture, from Theory to Practice. Springer, Dordrecht, pp. 197-207.

Liang, Y., Nikolic, M., Belanger, R., Gong, H. and Song, A. (2015b): Silicon in Agriculture, from Theory to Practice. Springer, Dordrecht, pp. 1-325.

Lowenstam, H. A. (1981): Minerals formed by organisms. Science 211, 1126-1131.

Ma, J. F. (2004): Role of silicon in enhancing the resistance of plants to biotic and abiotic stresses. J. Soil Sci. Plant Nutr. 50, 11-18.

Ma, J. F. and Takahashi, E. (2002): Soil, Fertilizer, and Plant Silicon Research in Japan. Elsevier, Amsterdam, Netherlands pp. 1-294.

Ma, J. F. and Yamaji, N. (2006): Silicon uptake and accumulation in higher plants. Trends Plant Sci. 11, 392-397.

Massey, F. P. and Hartley, S. E. (2009): Physical defences wear you down: progressive and irreversible impacts of silica on insect herbivores. J. Anim. Ecol. 78, 281-291.

Massey, F. P., Ennos, A. R. and Hartley, S. E. (2006): Silica in grasses as a defence against insect herbivores: contrasting effects on folivores and a phloem feeder. J. Anim. Ecol. 75, 595-603.

McColloch, J. W. and Salmon, S. C. (1923): The resistance of wheat to the hessian fly-a progress report. J. Econ. Entomol. 16, 293-298.

Mditshwa, A., Bower, J. P., Bertling, I., Mathaba, N. and Tesfay, S. T. (2013): The potential of postharvest silicon dips to regulate phenolics in citrus peel as a method to mitigate chilling injury in lemons. Afr. J. Biotechnol. 12, 1482-1489.

Mebrahtu, T., Kenworthy, W. J. and Elden, T. C. (1988): Inorganic nutrient analysis of leaf tissue from soybean lines screened for Mexican bean beetle resistance. J. Entomol. Sci. 23, 44-51.

Meyer, J. H. and Keeping, M. G. (2005): Impact of silicon in alleviating biotic stress in sugarcane in South Africa. Sugarcane Int. 23, 14-18.

Miller, B. S., Robinson, R. J., Johnson, J. A., Jones, E. T. and Ponnaiya, B. W. X. (1960): Studies on the relation between silica in wheat plants and resistance to Hessian fly. J. Econ. Entomol. 53, 995-999.

Nakata, Y., Ueno, M., Kihara, J., Ichii, M., Taketa, S. and Arase, S. (2008): Rice blast disease and susceptibility to pests in a silicon uptake-deficient mutant lsil of rice. Crop Prot. 27, 865-868.

Neri, D. K. P., Moraes, J. C. and Gavino, M. A. (2005): Interaction of silicon with growth regulating insecticide in the management of fall armyworm Spodoptera frugiperda (J. E. Smith, 1797) (Lepidoptera: Noctuidae) in corn plants. Cienc. Agrotec. 29, 1167-1174.

Pan, Y. C., Eow, K. L. and Ling, S. H. (1979): The effect of bagasse furnace ash on the growth of plant cane. Sugar J. 42, 14-16.

Panda, N., Pradhan, B., Samalo, A. P. and Rao, P. S. P. (1975): Note on the relationship of some biochemical factors with the resistance in rice varieties to yellow rice borer. Indian J. Agr. Sci. 45, 499-501.

Ponnaiya, B. W. X. (1951): Studies on the genus Sorghum. II. The cause of resistance in sorghum to the insect pest Atherigona indica M. Madras Univ. J. 21, 203-217. 
Rajamani, K., Gunti, B. R., Vemuri, S. and Bellamkonda, R. (2013): Effect of silicon and nitrogen nutrition on pest and disease intensity in rice. J. Agr. Sci. Tech. A3, 568-574.

Ramachandran, R. and Khan, Z. R. (1991): Mechanisms of resistance in wild rice Oryza brachyantha to rice leaffolder Cnaphalocrocis medinalis (Guenee) (Lepidoptera: Pyralidae). J. Chem. Ecol. 17, 41-65.

Ranger, C. M., Singh, A. P., Frantz, J. M., Canas, L., Locke, J. C., Reding, M. E. and Vorsa, N. (2009): Influence of silicon on resistance of Zinnia elegans to Myzus persicae (Hemiptera: Aphididae). Environ. Entomol. $38,129-136$.

Rao, S. D. V. (1967): Hardness of sugarcane varieties in relation to shoot borer infestation. Andhra Agric J. 14, 99-105.

Raupp, M. J. (1985): Effects of leaf toughness on mandibular wear of the leaf beetle, Plagiodera versicolora. Ecol. Entomol. 10, 73-79.

Redmond, C. T. and Potter, D. A. (2007): Silicon fertilization does not enhance creeping bentgrass resistance to cutworms and white grubs. USGA Turfgrass Environ. Res. 6, 1-7.

Reynolds, O. L., Keeping, M. G. and Meyer, J. H. (2009): Silicon-augmented resistance of plants to herbivorous insects: a review. Ann. Appl. Biol. 155, 171-186.

Reynolds, O. L., Connick, V. J., Simmons, A. T., Guisard, Y., Nicol, H. I., An, M. and Gurr, G. M. (2014): Silicon alters the volatile profile of pest-infested grapevines and increases attractiveness to predators. Proc. of the sixth International Conference on Silicon in Agriculture, Stockholm, Sweden, $152 \mathrm{p}$.

Reynolds, O. L., Padula, M. P., Zeng, R. and Gurr, G. M. (2016): Silicon: potential to promote direct and indirect effects on plant defense against arthropod pests in agriculture. Front. Plant Sci. 7, 744 p.

Rojanaridpiched, C., Gracen, V. E., Everett, H. L., Coors, J. G., Pugh, J. G., Pugh, B. F. and Bouthyette, T. (1984): Multiple factor resistance in maize to European corn borer. Maydica 29, 305-315.

Sakr, N. (2016a): Silicon control of bacterial and viral diseases in plants. J. Plant Prot. Res. 56, 331-336.

Sakr, N. (2016b): The role of silicon (Si) in increasing plant resistance against fungal diseases. Hellenic Plant Protect. J. 9, 1-15.

Salim, M. and Saxena, R. C. (1992): Iron, silica and aluminum stresses and varietal resistance in rice: Effects on whitebacked planthopper. Crop Sci. 32, 219-312.

Santa-Cecilia, L. V. C., Prado, E. and Moraes, J. C. (2014): Evaluation of silicon on the probing behavior of the citrus mealybug [Planococcus citri (Risso) (Pseudococcidae)] in coffee. Coffee Sci. 9, 10-13.

Sasamoto, K. (1961): Resistance of the rice plant applied with silicate and nitrogen fertilizers to the rice stem borer, Chilo suppressalis Walker. Proc. of the Faculty of Liberal Arts and Education, University of Yamanasaki, Japan, pp. 1-74.

Savant, N., Snyder, G. and Datnoff, L. (1997): Silicon management and sustainable rice production. Adv. Agron. $58,151-199$.

Savant, N. K., Korndorfer, G. H., Datnoff, L. E. and Snyder, G. H. (1999): Silicon nutrition and sugarcane production: a review. J. Plant Nutr. 22, 1853-1903.

Setamou, M., Schulthess, F., Bosque-Perez, N. A. and Thomas-Odjo, A. (1993): Effect of plant nitrogen and silica on the bionomics of Sesamia calamistis (Lepidoptera: Noctuidae). Bull. Entomol. Res. 83, 405-411.

Sharma, V. K. and Chatterji, S. M. (1972): Studies on some chemical constituents in relation to differential susceptibility of some maize germplasms to Chilo zonellus (Swinhoe). Indian J. Agr. Sci. 42, 457-461.

Sidhu, J. K., Stout, M. J., Blouin, D. C. and Datnoff, L. E. (2013): Effect of silicon soil amendment on performance of sugarcane borer, Diatraea saccharalis (Lepidoptera: Crambidae) on rice. Bull. Entomol. Res. 103, 565-664.

Singh, B., Yazdani, S. S. and Singh, R. (1993): Relationship between biochemical constituents of sweet potato cultivars and resistance to weevil (Cylas formicarius Fab.) damage. J. Entomol. Res. 17, 283-288.

Soliman, A. M., El-Atta, W. M., Elela, R. G. and Abdel-Wahab, A. E. (1997): Effect of certain chemical components and source of rice plant on its resistance to rice stem borer, Chilo agamemnon Bles. and rice leaf miner, Hydrellia prosternalis Deem. Egypt. J. Agr. Res. 75, 667-680.

Stanley, J. N., Baqir, H. A. and McLaren, T. I. (2014): Effect on larval growth of adding finely ground silicon-bearing minerals (wollastonite or olivine) to artificial diets for Helicoverpa spp. (Lepidoptera: Noctuidae). Aust. Entomol. 53, 436-443. 
Sunio, L. M., Caldo, R. and Cohen, M. B. (2000): Field screening of stem borer resistance in new plant type lines. Int. Rice Res. Notes 25, 25-27.

Takahashi, E., Ma, J. F. and Miyake, Y. (1990): The possibility of silicon as an essential element for higher plants. Comm. Agric. Food Chem. 2, 99-122.

Tomquelski, G. V., Martins, G. L. and Papa, G. (2007): Effect of resistance inductors acibenzolar-S-methyl and silicon in the biology of Alabama argillacea (Lepid.: Noctuidae) on crop cotton. Rev. Agric. (Piracicaba) $82,170-175$.

Ukwungwu, M. N. (1990): Host plant resistance in rice to the African striped borer, Chilo zacconius Bles. (Lepidoptera: Pyralidae). Insect Sci. Appl. 11, 639-647.

Van Bockhaven, J., Vleesschauwer, D. D. and Hofte, M. (2013): Towards establishing broad-spectrum disease resistance in plants: silicon leads the way. J. Exp. Bot. 64, 1281-1293.

Vieira, D. L., Vieira, V de Oliveira., de Souza, W. C. O., da Silva, J. G., Malaquias, J. B. and Batista, J. de Luna (2016): Potassium silicate-induced resistance against blackfly in seedlings of Citrus reticulate. Fruits 71, 49-55.

Ye, M., Song, Y. Y., Long, J., Wang, R. L., Baerson, S. R., Pan, Z. Q., Zhu-Salzman, K., Xie, J., Cai, K., Luo, S. and Zeng, R. (2013): Priming of jasmonate-mediated antiherbivore defense responses in rice by silicon. Proc. Natl Acad. Sci. U.S.A. 110, E3631-E3639.

Yoshihara, T. and Sogawa, K. (1979): Soluble silicic acid and insoluble silica contents in leaf sheaths of rice varieties carrying different BPH-resistance genes. Int. Rice Res. New. 4, 12-13.

Zadda, K., Ragjendran, R. and Vijayaraghavan, C. (2007): Induced systemic resistance to major insect pests of brinjal through organic farming. Crop Res. 34, 125-129. 
